\title{
Characterizing the Urban Decadal Expansion and Its Morphology Using Integrated Spatial Approaches in Semi-Arid Mountainous Environment, Saudi Arabia
}

\author{
Ahmed Ali Bindajam ${ }^{1}$, Javed Mallick ${ }^{2 *}$, Akanksha Balha ${ }^{3}$, Saeed Al Qadhi², \\ Ahmed Ali A. Shohan ${ }^{1}$, Chander Kumar Singh ${ }^{3}$, Atiqur Rahman ${ }^{4}$ \\ ${ }^{1}$ Department of Architecture and Planning, College of Engineering, King Khalid University, Abha, \\ Kingdom of Saudi Arabia \\ ${ }^{2}$ Department of Civil Engineering, College of Engineering, King Khalid University, Abha, Kingdom of Saudi Arabia \\ ${ }^{3}$ Department of Energy and Environment, TERI School of Advanced Studies, New Delhi, India, \\ ${ }^{4}$ Urban Environmental \& Remote Sensing, Natural Science, Jamia Millia Islamia, New Delhi, India
}

Received: 13 December 2020

Accepted: 2 February 2021

\begin{abstract}
Urban sprawl and increasing population pose a significant problem for sustainable development of cities. The present research focuses on analyzing urban growth and spatial patterns in Abha and its surrounding cities of Asir region of Saudi Arabia during the period 1990-2018. Landsat satellite data used to prepare LULC maps for the years 1990, 2000 and 2018 using maximum likelihood supervised classification. The study uses a combined approach of several spatial, urban metrics and landscape expansion index to quantify the growth patterns, expansion approaches and spatial extent of urban areas. A massive increase of $+389 \%$ in built-up area is observed over temporal scale under investigation. The conversion of the natural landscape to built-up is observed as the leading cause of urbanization. It is found that the outlying method of urban expansion is the most dominant, followed by edge-expansion and infill. Spatial metrics show dispersion at the outlying and accumulation in the centre. It was observed that rate and intensity of urban expansion and sprawl is recorded to be higher during 2000-2018 in comparison to 1990-2000. Assessing land-use changes and urbanization growth trends using integrated spatial approaches are helpful in planning and resource management in the region for the present and future.
\end{abstract}

Keywords: urbanization, urban expansion intensity index, spatial metrics, Landscape Expansion Index (LEI), Saudi Arabia

*e-mail: jmallick@kku.edu.sa 


\section{Introduction}

Increased urban footprints and significant changes in land use land cover (LULC) are direct impacts of urbanization [1]. Unplanned urban growth has been the major challenge across the world. The drawbacks such as incompetency in recording of systematic changes in vast land cover in conventional ground-based techniques have resulted in large scale use of geospatial techniques. The availability of satellite products, spatial data, and geographic information system (GIS) based modeling has led to development of new approaches to analyze urban dynamics. In few studies [2-7], temporal analysis of LULC has been extended to future timeperiod to develop prospective planning. However, for the assessment of urbanization and its impacts, urban spatial patterns need to be quantified [8]. Thus, integration of remote sensing and GIS has become a significant source of research in delineation of urban areas and urban planning [9]. The use of spatial techniques helps in accurate monitoring of urban areas and characterization of the changes in urban fabric. The advancement in GIS has resulted in plethora of research studies based on mapping of LULC to measure the urban built-up, land cover and urban sprawl [10]. The utilization of satellite data helps in the widespread spatial and cost-effective assessment of urban growth on temporal scale $[8,11]$. The factors causing urbanization and urban sprawl could be easily derived using spatial metrics $[12,13]$ and LULC classification-based methods $[13,14]$.

Advances in geospatial techniques have made it much easier to evaluate the landscape and determine its morphological changes. Spatial (or landscape) metrics are an exhaustive way to describe the spatial characteristics or patterns of a landscape [12, 13, 15]. Various studies have been conducted to comprehend and measure the urban landscapes [16-18]. The spatial characteristics of natural landscapes (i.e. spatial metrics) are used to characterize the urban patterns [1923]. The metrics have proven helpful in understanding the evolution process of cities by explaining aggregation and disaggregation [24, 25]. Moreover, various categories of spatial metrics, known as the dispersion index and built-up density index, have also been used to analyze the cities having large scale urban landscapes [26]. These metrics were used to understand urban expansion processes, urban morphological changes, and to explain variability in land-use patterns. Kane et al. [27] assessed the urban landscapes based on shape complexity, diversity, fragmentation, and urban areas to examine urban sprawl. The spatial metrics are helpful in describing spatial heterogeneity in landscape $[19,28$ 31]. The pattern of urban expansion can be understood with the help of spatial expansion approaches. Several metrics have been developed to include dynamic changes, and one such metric is the Land Expansion Index (LEI), developed by Liu et al [32]. In computing spatial patterns of urban morphological changes and estimating urban expansion, LEI has proven to be useful [32-36]. Li et al. [37] has proposed a method focused on geographically weighted regression (GWR) to differentiate the relationship between urbanization and landscape trends along with the spatial heterogeneity. Several of the studies employed gravity center method to identify the changing gravity center of urban land mass during the specified time-period [36, 38, 39]. Other urban growth measurement methods include map density [13], urban expansion intensity [36, 39], builtup density [36], local and global entropy indices [40], spatial metrics combined with urban-rural gradient [41, 42] and gradient model merged with patch matrix [30].

The capital city of Asir region, Abha and its surrounding areas are dominant in natural vegetation such as scrub and rocky terrain, however, the region has experienced rapid urban development in recent decades [18]. Therefore, determining the urbanization trend and growth patterns in the region becomes necessary for holistic development of the region inclusive of the natural vegetation and land cover. This paper aims to delineate urban morphology and utilize spatial metrics and landscape expansion index (LEI) to analyze patterns of urbanization and urban expansion approaches in Asir region of Saudi Arabia during last three decades i.e., 1990-2018. We also compute the rate, the intensity, and the spatial patterns of urban expansion. The study would be useful in determining and describing changing trend and spatial arrangement of urban area, which would be beneficial for future urban planning.

The present study is significant as it defines the process and rate of urban expansion in a naturally dominated vegetative landscape of a growing city of Asir, the region which is less studied in terms of urban planning. The region under study has an arid climate, however, because of its topography and amicable climate, the city is has shown rapid urban growth. The impact of climate change is frequently observed over the region and therefore a sustainable urban planning is need of the region to minimize the impact of climate change.

\section{Study Area}

The capital city of Asir region, Abha and its surrounding cities situated on the south-western side of Saudi Arabia, is chosen as the study area for the present study. The region, lying between $17^{\circ} 59^{\prime} 21.452^{\prime \prime} \mathrm{N}$ and $18^{\circ} 30^{\prime} 33.812^{\prime \prime} \mathrm{N}$ latitude, and $42^{\circ} 18^{\prime} 56.269^{\prime \prime} \mathrm{E}$ and $42^{\circ} 56^{\prime} 25.909^{\prime \prime} \mathrm{E}$. covers an area of $2286.59 \mathrm{~km}^{2}$. The topography of the study area is undulating and its elevation varies between 1,038 and $2,990 \mathrm{~m}$ with a mean elevation of $2180 \mathrm{~m}$ above sea level. It covers more natural vegetation in comparison to any other region of Kingdom of Saudi Arabia. It has one of the richest and most diverse floristic regions of the area. Jabal Al-Sooda, one of the region's highest mountain, is in the north-western part of the of the study area 


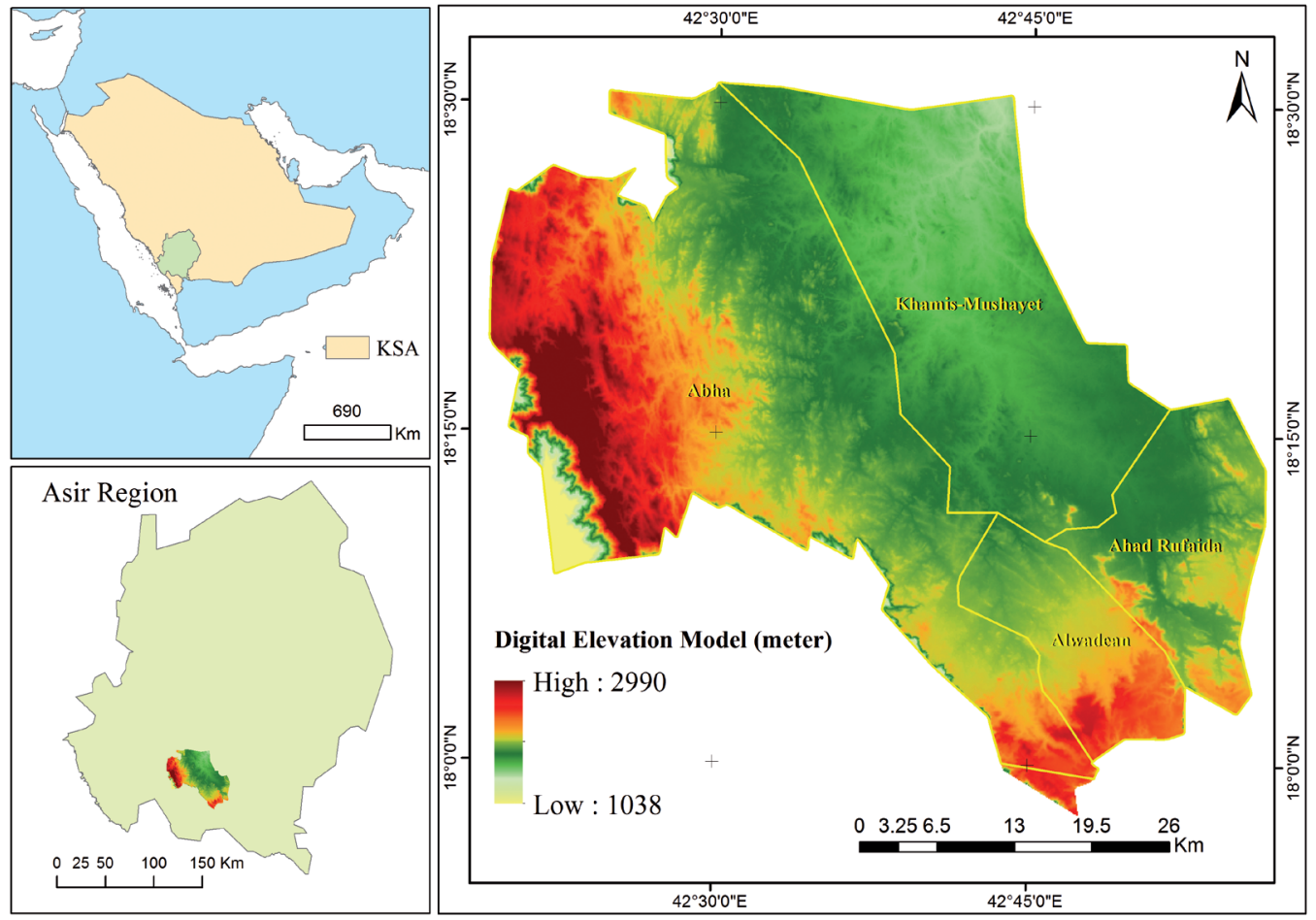

Fig. 1. Location map of study area showing the topographic of the study region.

with a height of $2990 \mathrm{~m}$ and also has a rich flora [43]. The variability in climate and topography has led to the development of various plant species within the study area (Asir Province) [44]. Because of anthropogenic activities, high slope, fragile geology and rainfall it has widespread land loss problem and thus creates ecological imbalances.

Among the surrounding cities, Abha city is presently the capital city of the Asir region. According to the General Statistics Authority's 2019 census, Abha, Khamis Mushyet, Alwadean and Ahad Rufaida, 2.2 million people live in these four cities, $1 / 3$ per cent of whom are Saudis $[45,46]$. The layout of these four cities typically leads to urban development in the region, including several topographical levels in most of its parts. Mountainous areas are the main drawing factors for tourists to those cities. The four major Asir region cities studied expect significant urban transformation growth, and address a sustainable understanding of urban sprawl and development that will enhance the quality of living for tourists and residents is a must.

\section{Data and Method Used}

\section{Pre-Processing}

Landsat satellite dataset for the years 1990, 2000, and 2018 were downloaded from USGS Earth Explorer (https://earthexplorer.usgs.gov/). The methodology flowchart is given in Fig. 2. The images were layerstacked using individual bands to form False Colour
Composite (FCC) images of each year. The decadal satellite images of Landsat images acquired were processed at Level-1 and thus processed to standard parameters and distributed as scaled and calibrated digital numbers (DN). The images were corrected radiometrically and geometrically. Later, they were orthorectified to common Universal Transverse Mercator (UTM) projection. Using ERDAS Imagine software 9.2 the individual bands obtained were stacked layer for further processing. The colour balancing technique [47] was used to minimize differences in visual appearance on the mosaicked image. This was followed by atmospheric correction using the Dark Object Subtraction (DOS) model, that depends on data from the image itself to correct atmospheric effects. This model takes into account minimum $\mathrm{DN}$ value in the histogram and is deducted from all the pixels. Finally, the image was subset using the study area administrative boundary.

\section{Image Classification and Accuracy Evaluation}

Supervised Maximum Likelihood Classification (MLC) algorithm has been adopted to categories the images into eight classes such as built-up, water bodies, sparse vegetation, dense vegetation, agricultural land, scrubland, bare soil, and exposed rocks lands. The training sets were chosen based on in between class spectral separability. This classification scheme was used based on best system of image classification [48]. The Maximum Likelihood Classification algorithm uses Bayesian Theorem of decision making and assigns 


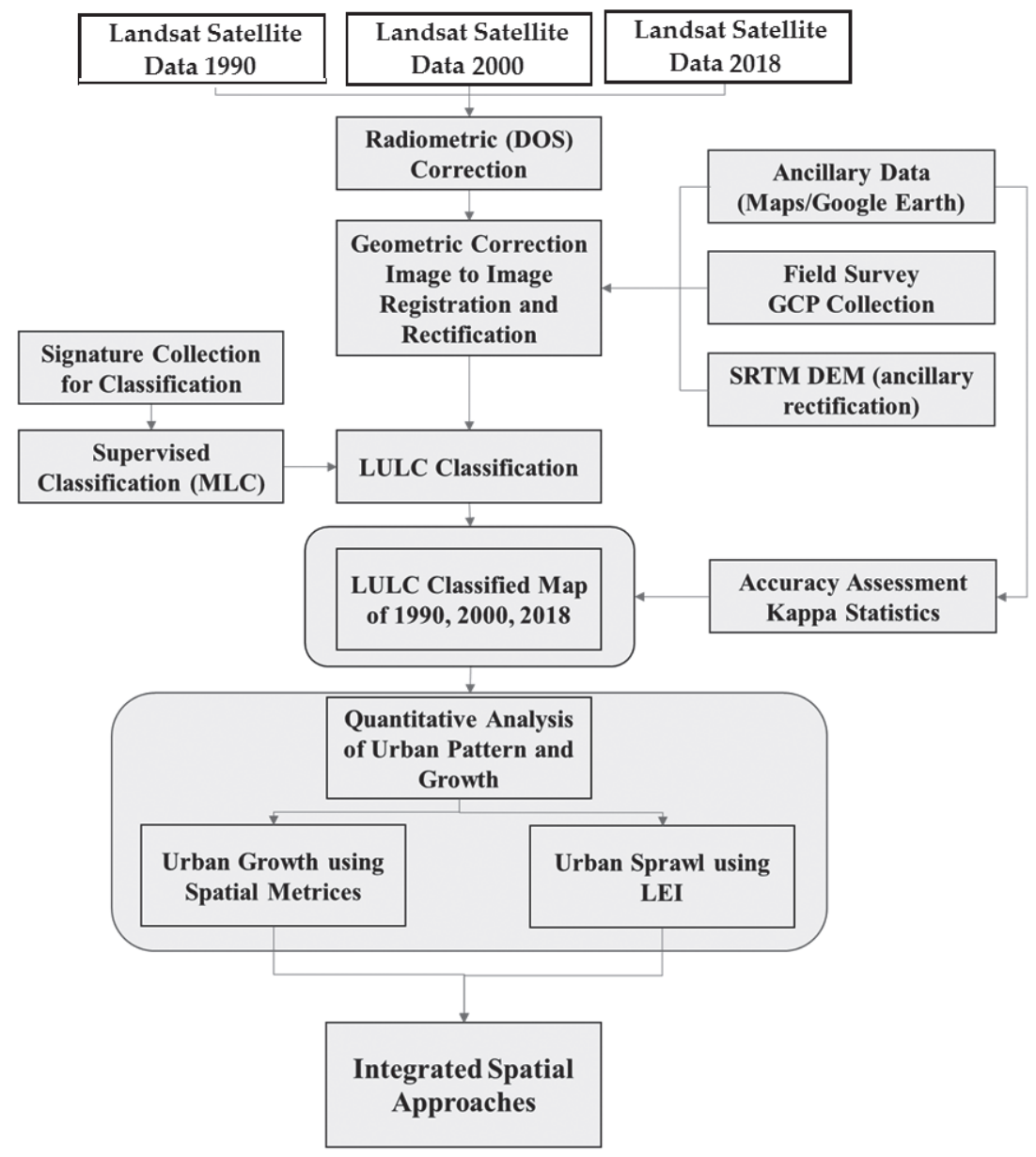

Fig. 2. Methodological Framework.

the pixel to the possible class based on the probability of a pixel belonging to a class [49]. When assigning a pixel to one of the classes, the MLC considers the variances and covariance of the class training sets. We trained the classifier until allowable separability indices were obtained based on the Bhattacharya distance separability index. To select the best $q$ features from the original $\mathrm{n}$ bands in an $m$-class problem, the Bhattacharyya distance is calculated between each $\mathrm{m}(\mathrm{m}-1) / 2$ pair of classes for each possible way of choosing $q$ features from $\mathrm{n}$ dimensions. The best $q$ features are those dimensions whose sum of the Bhattacharyya distance between the $\mathrm{m}(\mathrm{m}-1) / 2$ classes is highest [50]. Accuracy assessment for the image of 2018 was based on 112 GCPs collected during field survey using a handheld Garmin GPS and highresolution Worldview images of the region. A stratified random sampling was adopted to collect the GCP's from all the eight classes derived from LULC classification. The reference points for the image of 1990 were collected from the ancillary cadastral and topographic maps. The accuracy for the classified image of 2000 was assessed using google earth images for the year 2000 [51]. The google earth images are good for assessment of historic images and has been advocated to be useful in assessing the accuracy of classification [51, 52]. On the basis of the reference data, we calculated the areas of the mapped categories for the period under analysis to account for errors associated with the quantitative assessment of areas from classified data. To test corresponding classes, the field sample coordinates were overlaid on classified maps. Statistically, for accuracy assessment, the confusion matrix, derived from LULC maps and field data (signature file), as defined by Jensen [49], was developed. In addition, the Kappa and its variance were used to measure a coefficient of agreement between classified data and ground reference data. The importance of "overall accuracy, producer's accuracy, user's accuracy, and kappa coefficient" indicates the classification accuracy, in addition to the error margin for overall accuracy at $95 \%$ confidence interval.

\section{Urban Spatial Metrics}

The built-up areas are extracted from the classified LULC maps to examine spatial patterns in built-up or urban areas. With the advancement in satellite data and geoinformation techniques, spatial metrics have become a widely used technique to assess urban spatial patterns and quantify urban dynamics. The urban expansion/sprawl within a patch or region can be 
categorized as outlying, edge expansion, and infilling. The use of spatial adjacency relationships among different patches to identify the type of expansion types has been stated in Forman [53]. Fragstats [54] was used to analyze urban dynamics using spatial metrics in this study. The spatial metrics used in the study are given in Table 1.

\section{Landscape Expansion Index (LEI)}

LEI [32, 36] describes various urban expansion approaches i.e., infill, outlying and edge-expansion. LEI can obtain information on the establishment process of land expansion patterns. The spatial relationship between an existing builtup and new urban patches identifies the evolution of land use pattern. The index is calculated using Eq. (1) which determines phenomenon of urbanization during the given period. LEI was calculated as:

$$
L E I=100 \times \frac{A_{b o}}{A_{b o}+A_{b v}}
$$

...where $\mathrm{A}_{\mathrm{bo}}$ is the intersection area between buffer and occupied area of old urban land (i.e. of the previous year) and $\mathrm{A}_{\mathrm{bv}}$ is the intersection area between buffer and

Table 1. Different spatial metrics used in the study to understand urban dynamics [54].

\begin{tabular}{|c|c|c|c|c|}
\hline S.No & Spatial metric & Formula & Range & Description \\
\hline 1. & $\begin{array}{l}\text { "Class Area } \\
\text { (CA)" }\end{array}$ & $\begin{aligned} C A & =\sum_{j=1}^{n} a_{i j}\left(\frac{1}{10000}\right) \\
a_{i j} & =\text { area (m2) of patch } \mathrm{ij}\end{aligned}$ & $\mathrm{CA}>0$, no limit & $\begin{array}{l}\text { "The total sum area }\left(\mathrm{m}^{2}\right) \text { of all the patches } \\
\text { of a class; divided by } 10000 \text { for conversion } \\
\text { to hectares." Higher value means more area } \\
\text { covered by a particular class. }\end{array}$ \\
\hline 2. & $\begin{array}{l}\text { "Largest Patch } \\
\text { Index (LPI)" }\end{array}$ & $\begin{array}{c}L P I=\frac{\max _{j=1}^{n}\left(a_{i j}\right)}{A} \\
a_{i j}=\text { area }(\mathrm{m} 2) \text { of patch } \mathrm{ij} \\
\mathrm{A}=\text { total landscape area }\left(\mathrm{m}^{2}\right)\end{array}$ & $0<\mathrm{LPI} \leq 100$ & $\begin{array}{l}\text { "The area of the largest patch of the } \\
\text { corresponding class divided by total } \\
\text { landscape area." Higher value indicates when } \\
\text { particular class covers huge continuous area. }\end{array}$ \\
\hline 3. & $\begin{array}{l}\text { "Edge density } \\
\text { (ED)" }\end{array}$ & $\begin{array}{c}E D=\frac{\sum_{k=1}^{m} e_{i k}}{A} \\
\mathrm{e}_{\mathrm{ik}}=\text { total length }(\mathrm{m}) \text { of edge of } \\
\text { all patches of a class } \mathrm{i} \\
\mathrm{A}=\text { total landscape area }\left(\mathrm{m}^{2}\right)\end{array}$ & $\mathrm{ED} \geq 0$, no limit & $\begin{array}{l}\text { "The sum of lengths }(\mathrm{m}) \text { of all edges of all } \\
\text { patches of a class divided by total landscape } \\
\text { area }\left(\mathrm{m}^{2}\right) . \text {." Higher value means increasing } \\
\text { fragmentation of a particular class. }\end{array}$ \\
\hline 4. & $\begin{array}{l}\text { "Percentage } \\
\text { of Landscape } \\
\text { (PLAND)" }\end{array}$ & $P L A N D=P_{i}=\frac{\sum_{j=1}^{n} a_{i j}}{A}(100)$ & $\begin{array}{l}\quad 0<\text { PLAND } \leq 100 \\
\text { PLAND becomes } 0 \\
\text { when corresponding } \\
\text { patch type becomes rare; } \\
\text { PLAND = } 100 \text {, when en- } \\
\text { tire landscape comprises } \\
\text { of single patch types }\end{array}$ & $\begin{array}{l}\text { "It equals the percentage the total landscape } \\
\text { comprised of corresponding urban patch } \\
\text { type" }\end{array}$ \\
\hline 5. & $\begin{array}{l}\text { "Number of } \\
\text { patches (NP)" }\end{array}$ & $\begin{array}{c}N P-n_{i} \\
n_{i}=\text { number of patches in class } \\
\text { type } \mathrm{i}\end{array}$ & $\mathrm{NP} \geq 1$, no limit & $\begin{array}{l}\text { "The total number of patches of a class. } \\
\text { Higher number means increase in number of } \\
\text { patches of corresponding class" }\end{array}$ \\
\hline 6. & $\begin{array}{l}\text { "COHESION } \\
\text { (Patch } \\
\text { Cohesion } \\
\text { Index)" }\end{array}$ & $\begin{array}{c}{\left[1-\frac{\sum_{j=1}^{n} p *_{i j}}{\sum_{j=1}^{n} p *_{i j} \sqrt{a *_{i j}}}\right] .} \\
{\left[1-\frac{1}{\sqrt{Z}}\right] \cdot(100)} \\
\text {...where } \mathrm{p}^{*}{ }_{\mathrm{ij}}=\text { perimeter of } \\
\text { patch ij; } \mathrm{a}^{\mathrm{ij}}=\text { area of patch } \mathrm{ij} \\
\mathrm{Z}=\text { total number of cells in } \\
\text { landscape }\end{array}$ & $0<\mathrm{CONTAG} \leq 100$ & $\begin{array}{l}\text { "CONTAG equals minus the sum of the } \\
\text { proportional abundance of each patch type } \\
\text { multiplied by the proportion of adjacencies } \\
\text { between cells of that patch type and another } \\
\text { patch type, multiplied by the } \\
\text { logarithm of the same quantity, summed over } \\
\text { each unique adjacency type and each patch } \\
\text { type; divided by } 2 \text { times the logarithm of the } \\
\text { number of patch types, multiplied by } 100 \\
\text { (to convert to a percentage)." Higher value } \\
\text { means large continuous class. }\end{array}$ \\
\hline 7. & $\begin{array}{l}\text { Landscape } \\
\text { Shape Index } \\
\quad \text { (LSI) }\end{array}$ & $\begin{array}{c}L S I=\frac{0.25 \sum_{k=}^{m} e_{i k}^{*}}{\sqrt{A}} \\
\ldots \text { where } e_{i k}^{*} \text { is total length of } \\
\text { edge between patch types } \mathrm{i} \text { and } \\
\mathrm{k}, \mathrm{A}=\text { total landscape area }\left(\mathrm{m}^{2}\right)\end{array}$ & $\begin{array}{l}\text { LSI } \geq 1 \text {, without limit } \\
\text { LSI = } 1 \text { when landscape } \\
\text { comprises of single } \\
\text { square patch. } \\
\text { LSI increases without } \\
\text { limit as it becomes more } \\
\text { irregular/edge length of } \\
\text { patch types increases. }\end{array}$ & $\begin{array}{l}\text { It represents a standardized measure of total } \\
\text { edge/ edge density. }\end{array}$ \\
\hline
\end{tabular}




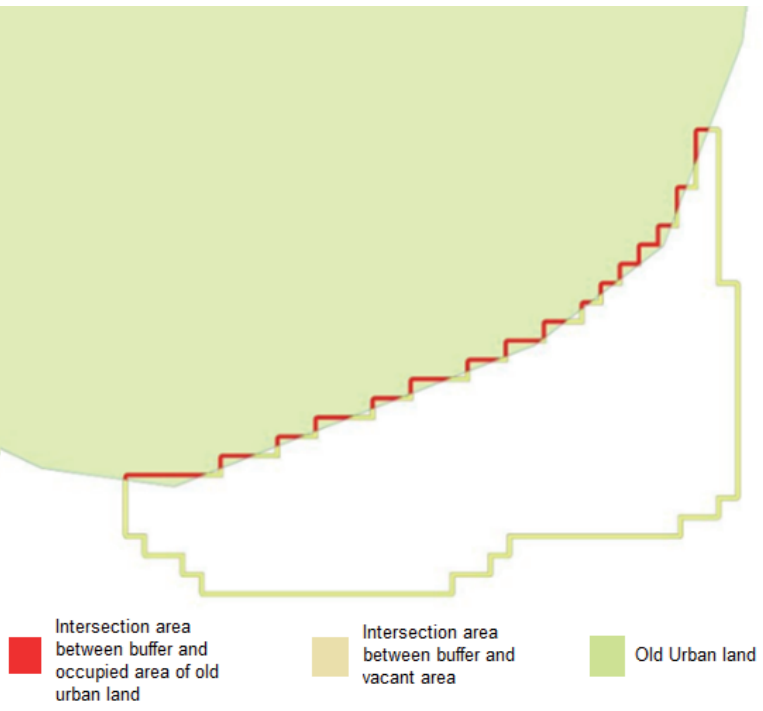

Fig. 3. Diagrammatic representation of LEI parameters.

vacant area (Fig. 3)" The vacant area is the new urban land (i.e. of later year) [32].

LEI was computed using urban areas for different time scales. Using the vector form of new urban areas, buffers of $1 \mathrm{~m}$ were created. The buffer distance of $1 \mathrm{~m}$ is chosen because the study area has deserted landscape and therefore, the urban expansion of a minimal yet appropriate magnitude is intended to be captured and observed to assess the process of urbanization. Thus, $1 \mathrm{~m}$ distance was chosen as the most appropriate buffer distance as it can cover considerable urban expansion in the study region over the temporal domain.

\section{Urban Expansion Indices}

To estimate rate, intensity and phenomenon of urbanization, three indices were used, i.e., Urban Expansion Rate (UER) [32], Urban Expansion Intensity Index (UEII) and Urban Growth Coefficient (UGC) $[55,56]$. Urban Expansion Rate (UER) estimates average annual rate of urban expansion between two time periods using Eq. 2.

$$
U E R=\left[\left(\frac{U_{t 2}}{U_{t 1}}\right)^{\frac{1}{t 2-t 1}}-1\right] * 100
$$

...where, UER is Urban Expansion Rate, $\mathrm{U}_{\mathrm{t} 2}$ and $\mathrm{U}_{\mathrm{t} 1}$ are built-up area at time-period $t_{1}$ and $t_{2}$, respectively. Urban Expansion Intensity Index (UEII) indicates mean annual proportion of newly increased built-up area with respect to total changed area [55]. UEII is calculated using Eq. 3.

$$
U E I I=\frac{U_{t 2}-U_{t 1}}{T A \times t} \times 100
$$

...where, $\mathrm{U}_{\mathrm{t} 2}$ and $\mathrm{U}_{\mathrm{t} 1}$ are built-up area at time-period $\mathrm{t}_{1}$ and $t_{2}$, respectively, TA is total area of landscape and $t$ is time-period i.e., $t_{2}-t_{1}$. UEII is considered to reveal the possibility, intensity (speed) and future direction of urbanization [56].

To identify the pattern of urbanization i.e., sprawl or densification, Urban Growth Coefficient (UGC) was calculated using Eq. 4.

$$
U G C=\frac{U_{r}}{P_{r}}
$$

...where, $\mathrm{U}_{\mathrm{r}}$ means urbanization rate and $\mathrm{P}_{\mathrm{r}}$ is urban population growth.

The value of $\mathrm{UGC}>1$ indicates urban expansion as sprawling phenomenon and $<1$ as densification [55].

\section{Results and Discussion}

\section{Accuracy Assessment}

The LULC maps for years 1990, 2000 and 2018 are generated by classifying Landsat satellite images of respective years using MLC algorithm. The accuracy assessment of the classified LULC maps was done using confusion matrix. The producer's and user's accuracies values of classified LULC maps for respective years are given in Fig 4. The overall classification accuracy values for the classified LULC maps of 1990, 2000, and 2018 are found to be $89.74 \%, 88.40 \%$ and $91.21 \%$, respectively. The kappa coefficient values for the classified LULC maps of 1990, 2000, and 2018 are observed to be $0.86,0.85$ and 0.90 , respectively. Fig. 4 shows that the classification accuracy of different LULC classes is equal to or more than $75 \%$. It indicates that the accuracy of the classified LULC maps is satisfactory for further analysis.

\section{Spatio-Temporal LULC Analysis}

Spatio-temporal changes in LULC of Asir region were analysed over a period of almost three decades from 1990-2018. Fig. 2 shows the classified LULC maps of 1990, 2000 and 2018. The quantification of area covered by each LULC class in classified LULC maps (Table 2) reveal continuous increase in built-up area of $389.27 \%$ during 1990-2018 (Fig. 5). Spatially, the region has observed increase in built-up area in north and south-east direction. The dense and sparse vegetation has shown increase over the temporal scale considered in the study. This could be attributed to maintain the national park region in the north-western side of Asir, which constitutes mainly dense and sparse vegetation. The LULC features such as agricultural land, scrubland and bare soil have experienced a decline (Fig. 6). It could be attributed to human dominated activities leading to conversion to built-up area. The exposed rock region is observed to first increase and later decrease due to different land-use change processes.

In 1990, rocky terrain is covered with natural vegetation. Over the years, natural vegetation covering 


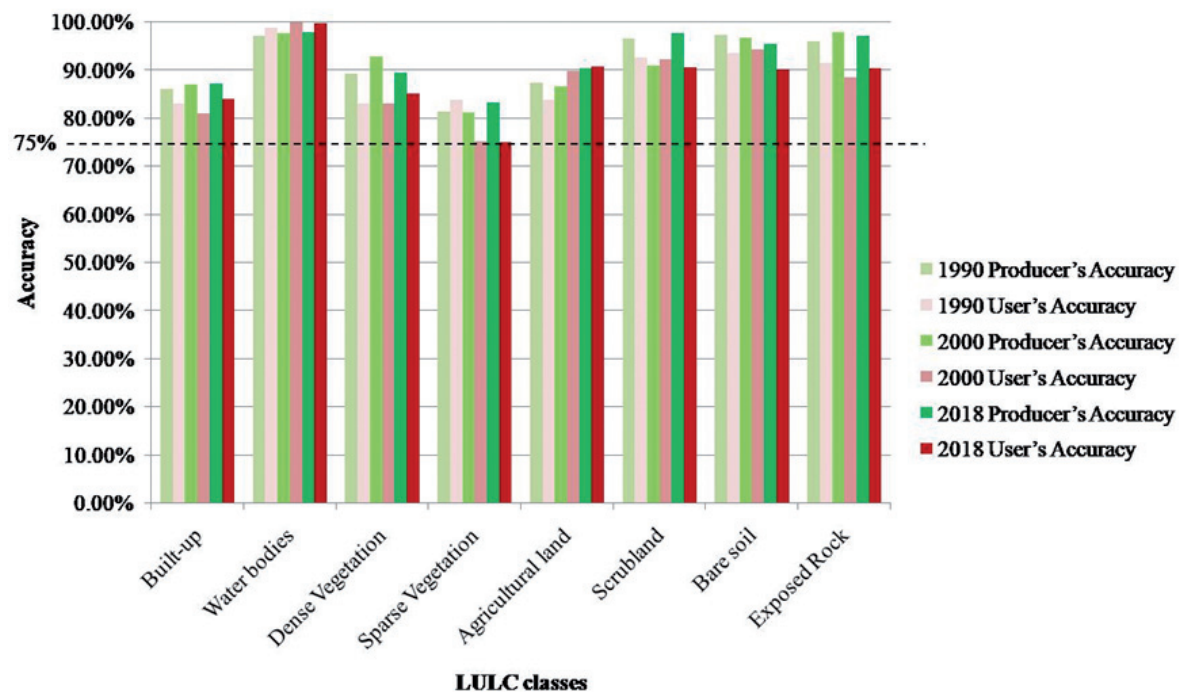

Fig. 4. The user and producer accuracy for different LULC classes for the classified map of year 1990, 2000 and 2018.

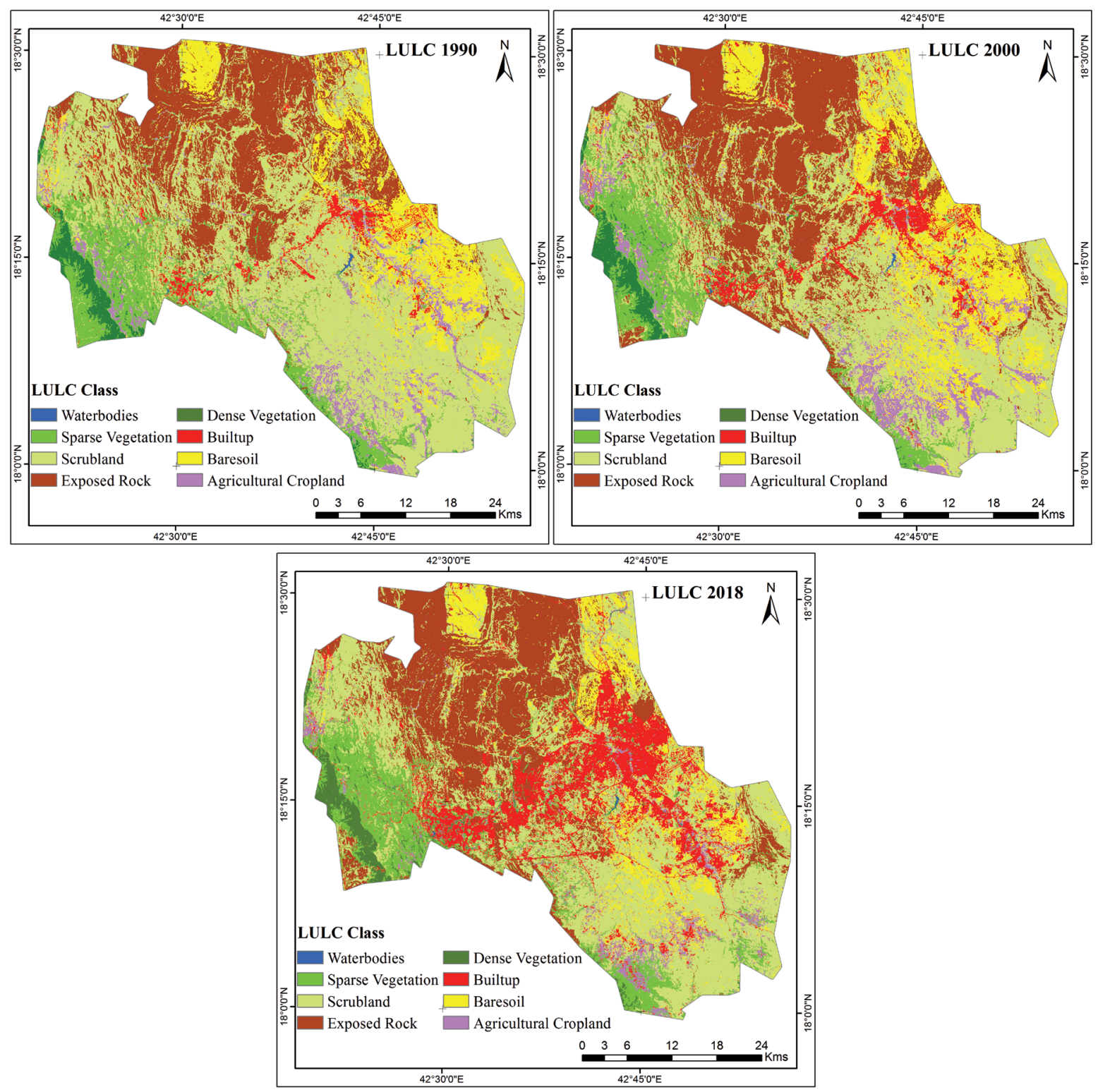

Fig. 5. LULC maps of Asir for different time-periods. 




Fig. 6. Spatio-temporal extent of agriculture, baresoil, builtup and dense veg. during 1990-2018.

Table 2. Area (in $\mathrm{km}^{2}$ ) covered by LULC classes during 1990-2018.

\begin{tabular}{|c|c|c|c|}
\hline LULC classes & 1990 & 2000 & 2018 \\
\hline Built-up & 69.43 & 117.75 & 339.70 \\
\hline Water bodies & 1.51 & 1.14 & 0.53 \\
\hline Dense vegetation & 45.69 & 48.13 & 54.67 \\
\hline Sparse vegetation & 242.52 & 208.25 & 253.50 \\
\hline Agricultural land & 110.67 & 140.28 & 67.75 \\
\hline Scrubland & 1048.42 & 801.00 & 842.69 \\
\hline Bare soil & 263.58 & 355.74 & 186.91 \\
\hline Exposed rock & 504.77 & 614.30 & 540.84 \\
\hline
\end{tabular}




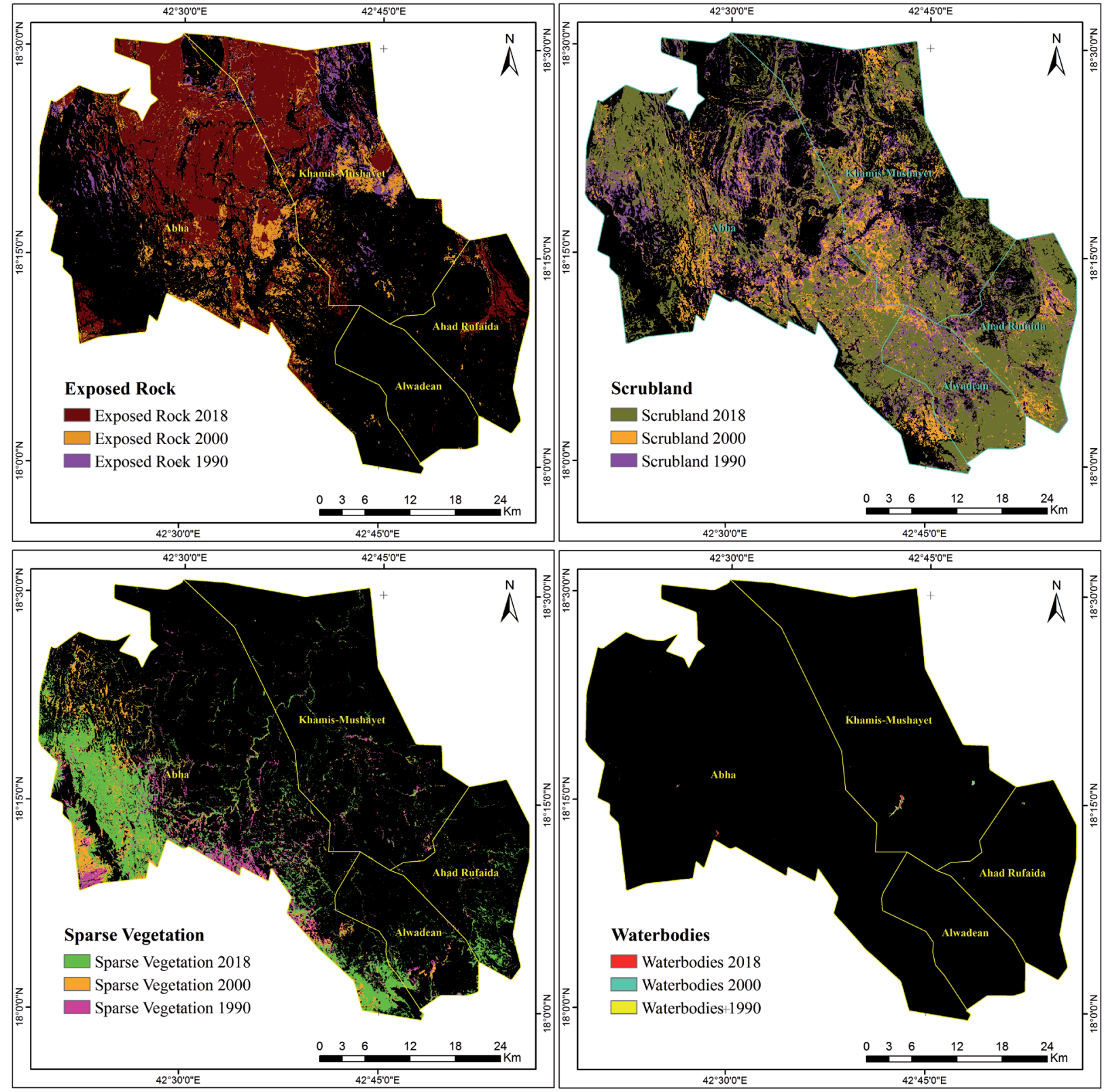

Fig. 7. Spatio-temporal extent of exposed rock, scrubland, sparse vegetation and waterbodies during 1990-2018.

the rocky terrain declined due to anthropogenic activities, leading the exposed area open or covered with baresoil. This has led to increase in baresoil area and exposed rock during 1990-2000. However, during 2000-2018, exposed rocky terrain as well as baresoil area declined due to its conversion to built-up. To understand the changing landscape and spatial extent of various LULC classes over the years, spatio-temporal maps for each LULC are prepared separately (Fig. 6 and 7).

\section{Spatial Metrics}

Using the built-up class masked out from the LULC maps of 1990, 2000 and 2018 (Fig. 8), spatial metrics have been calculated on class levels to understand the urban areas heterogeneity (Fig. 9 and Table 3). Analysis at class level is useful to understand spatial arrangement of patches in each class [57]. As various metrics are redundant, the present study has chosen and employed eight metrics to analyze the spatial arrangement and structure of urban landscape.

During 1990-2018, a huge increase in the values of Total Class Area (CA) (6943 in 1990, 11775 in 2000 and 33970 in 2018) is observed (Table 3). It shows that spatial metrics affirm the increase in the built-up area derived from LULC maps. The increase in values of Percentage of Landscape (PLAND) i.e., 1.81 in 1990 to 3.07 in 2000 shows the increase in the abundance of built-up class. A higher abundance in built-up class is observed with higher increase in the PLAND values (3.07 in 2000 to 8.87 in 2018) during 2000-2018. 


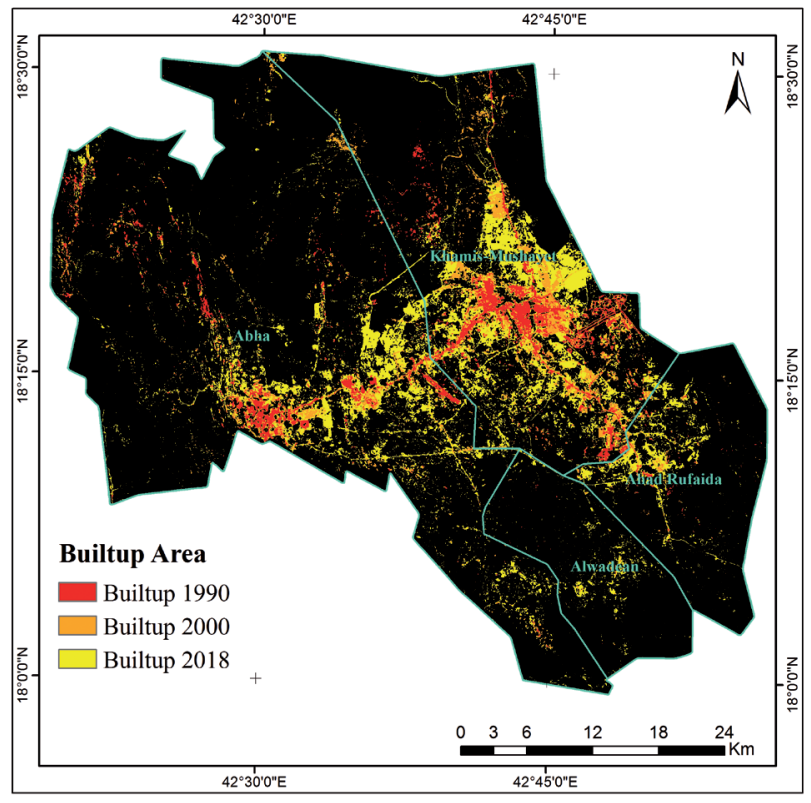

Fig. 8. Spatial extent of built-up during 1990-2018.

Increase in the values of Largest Patch Index (LPI) (0.41 in 1990, 0.90 in 2000, and 5.77 in 2018) shows increasing dominance by the area covered by built-up class in the study region.

With 5.77 value in LPI, built-up area is observed as a dominant LULC class in 2018. Also, it indicates aggregation of built-up area with time. Another metric, Edge Density (ED) indicates formation of new patches. Therefore, ED results show that the time-period 2000-2018 experience formation of new patches of built-up in comparison to time-period 1990-2000. Similar inference can be derived from the values of Number of Patches (NP) i.e., 2533 in 1990, 3791 in 2000 and 10844 in 2018. A significant increase in the number of patches is found during 2000-2018 in comparison to that of 1990-2000. The higher calculated Patch Cohesion Index (COHESION) values (96.52 in 1990, 97.83 in 2000 and 99.45 in 2018) represent aggregated distribution built-up patches spatially. The higher COHESION values of built-up in 1990 indicates builtup class to be contagious, however, built-up patches are observed to get more clumped and clustered in 2018. Landscape Shape Index (LSI) reveals about the shape of the class patches. An increase in LSI values (57.19 in 1990 to 64.63 in 2000 to 95.57 in 2018) indicates higher irregularity in the built-up class patches. A greater irregularity is observed in 2018 as compared to 2000 . Higher LSI values are also indicative of increasing edge lengths.

\section{Spatial Expansion Approaches}

The LEI was used to analyse spatial expansion methods of urban expansion i.e. outlying, edge expansion and infill, and determine the evolution of urban areas in Asir region. LEI 's value varies from 0 to 100. Several attempts have been made to set appropriate thresholds to define various urban spatial approaches [32] using histogram distribution of number of patches and LEI values for different temporal scales. The peaks can provide the evidence to set the thresholds of LEI values for determining the urban patch growth types Using the calculated LEI values, a certain LEI interval is allotted a spatial expansion approach type based on visual investigation of the urban patches. The threshold employed for LEI for the spatial expansion during the period 1990-2000 was LEI $=0<21.88$ signifying outlying: LEI $>21.88<59.84$ as edge-expansion and LEI $>59.84<100$ as infill, whereas for the period 2000-2018 was LEI $=0<20.94$ signifying outlying: LEI $>20.94<60.50$ as edge-expansion and LEI $>60.50$

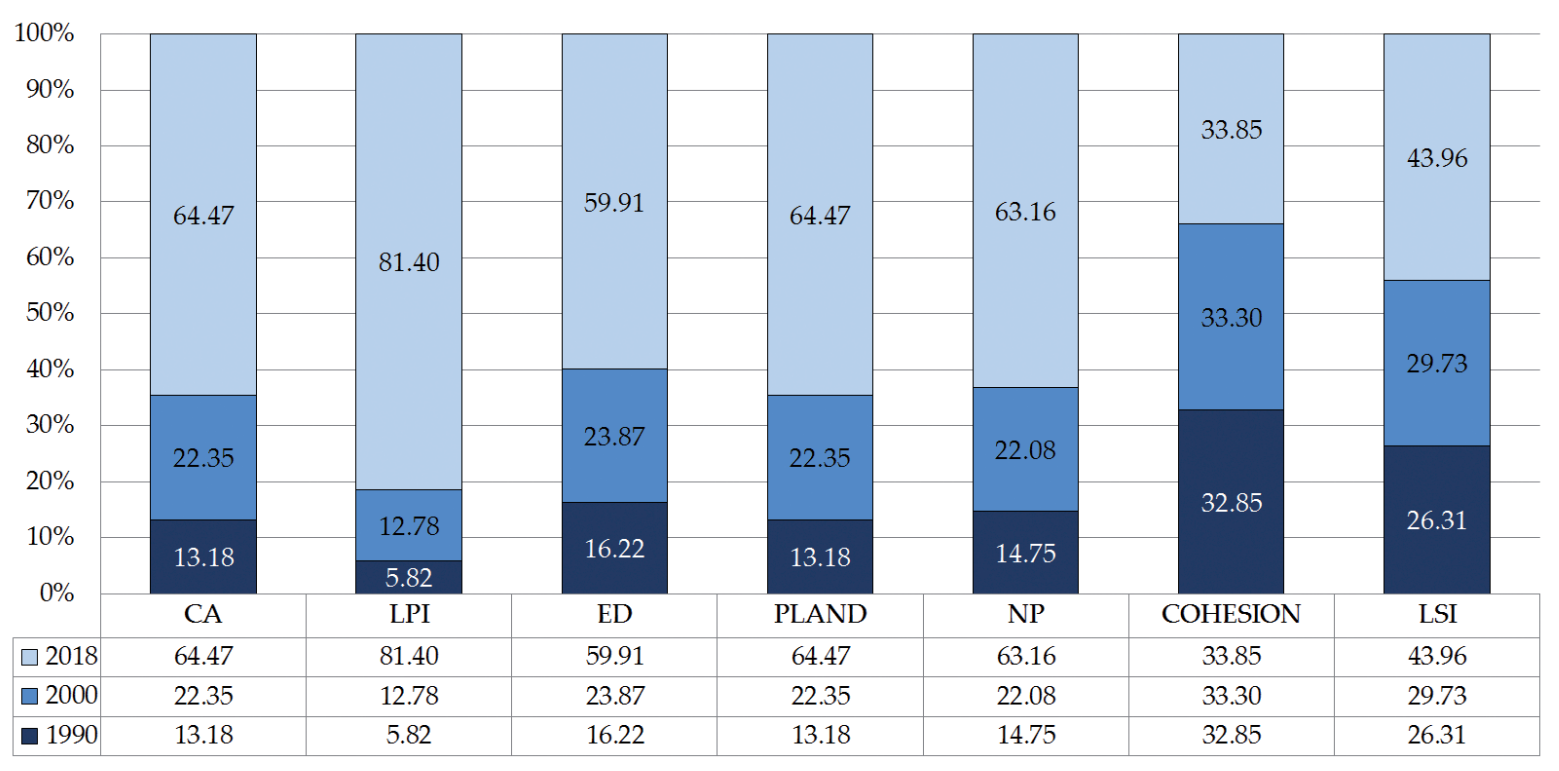

Fig. 9. Graphical representation of spatial metrics of urban area (\%) during 1990-2018. 
Tbale 3. Spatial metrics of urban area during 1990-2018.

\begin{tabular}{|c|c|c|c|c|}
\hline & $\mathbf{1 9 9 0}$ & $\mathbf{2 0 0 0}$ & $\mathbf{2 0 1 8}$ & Total \\
\hline CA & 6943.95 & 11775.24 & 33970.50 & 52689.69 \\
\hline$\%$ & 13.18 & 22.35 & 64.47 & 5.78 \\
\hline LPI & 0.41 & 0.91 & 81.40 & 100.00 \\
\hline$\%$ & 5.82 & 12.78 & 18.42 & 30.74 \\
\hline ED & 4.99 & 7.34 & 59.91 & 100.00 \\
\hline$\%$ & 16.22 & 23.87 & 8.88 & 13.77 \\
\hline PLAND & 1.81 & 3.08 & 64.47 & 100.00 \\
\hline$\%$ & 13.18 & 22.35 & 10844.00 & 17168.00 \\
\hline NP & 2533.00 & 3791.00 & 63.16 & 100.00 \\
\hline$\%$ & 14.75 & 22.08 & 99.46 & 293.82 \\
\hline COHESION & 96.53 & 97.83 & 33.85 & 100.00 \\
\hline$\%$ & 32.85 & 33.30 & 95.57 & 217.39 \\
\hline LSI & 57.19 & 64.63 & 43.96 & 100.00 \\
\hline
\end{tabular}

$<100$ as infill. Fig. 10 shows the spatial variability of urban expansion approaches and area covered by edgeexpansion, outlying and infill during 1990-2000 and 2000-2018, respectively (Fig. 11).

Hence, these findings derived from LULC maps, spatial metrics and spatial expansion approach reveal that the initially in 1990, built-up area, located in the centre of the Asir region, was spatially contagious. Later in 2000 and 2018, the region has experienced a huge increase in the number of new built-up patches in the outskirt's region as well as expansion in the already existing urban land leading to the formation of huge contiguous urban area. This has led urban patches to cause dispersion in the outskirts and aggregation in the centre of the study area.

\section{Quantification of Urban Expansion}

Urban expansion is measured based on urban area between two specified time-periods 1990-2000
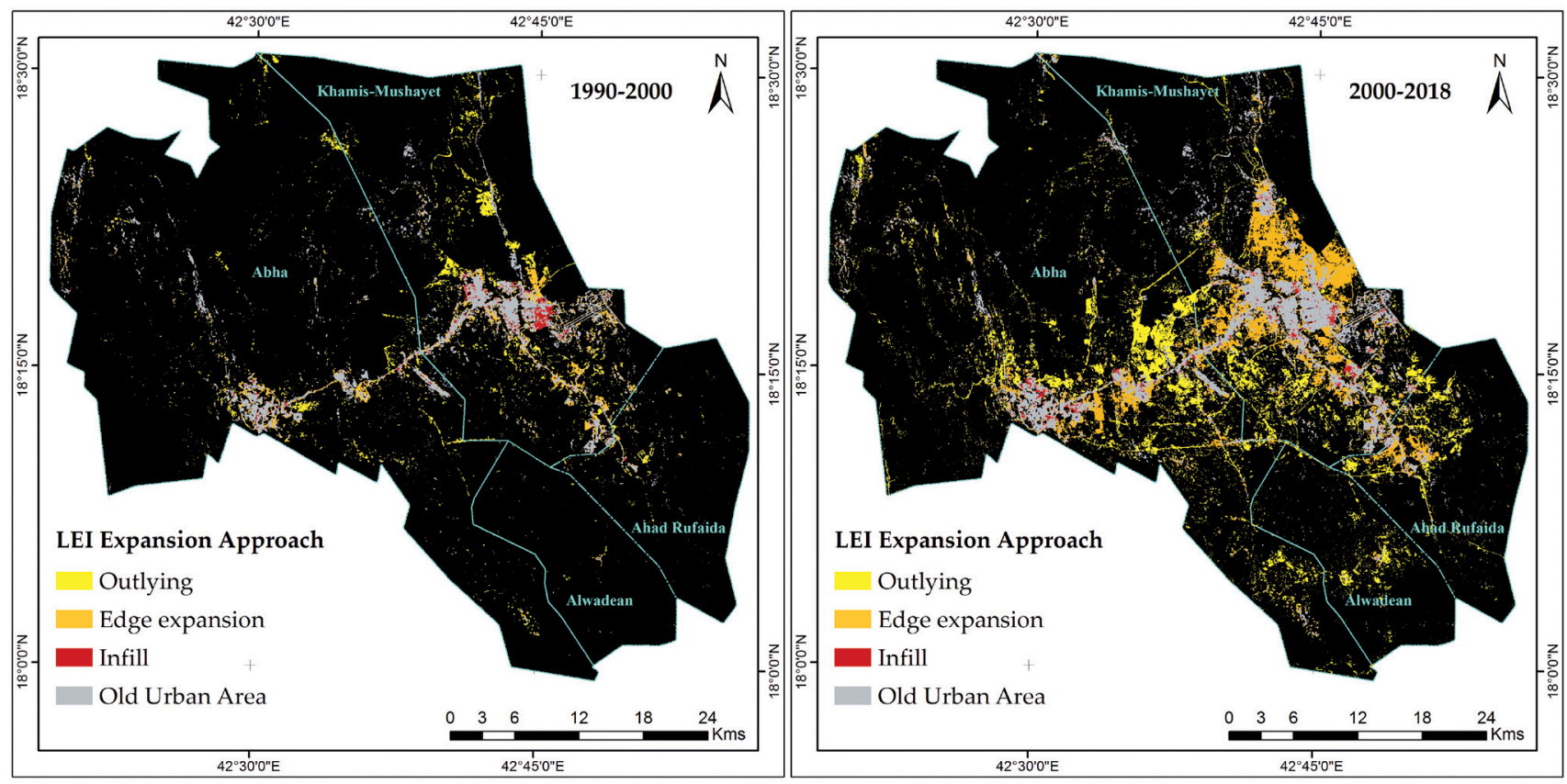

Fig. 10. LEI maps for 1990-2000 and 2000-2018. 


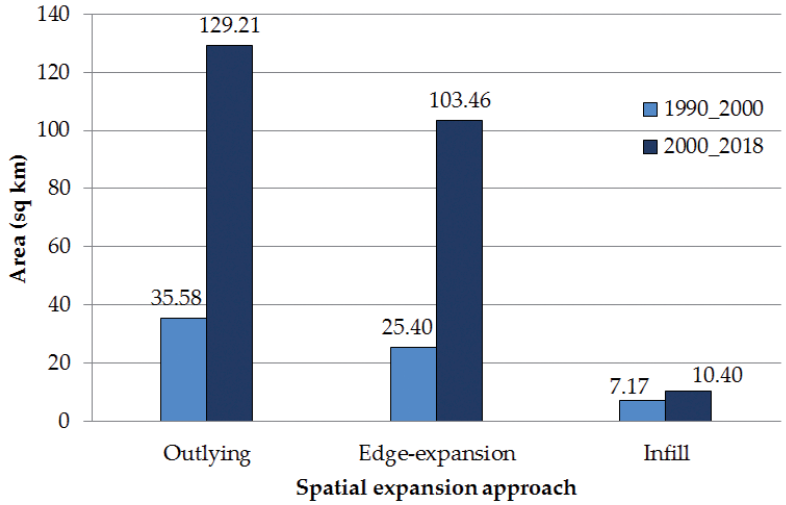

Fig. 11. Area covered by spatial expansion approach during 1990-2000 and 2000-2018.

and 2000-2018. The LULC maps have revealed the spatial extent of built-up area during different time-periods; thus, have provided a direct estimate of urban expansion in the study area. The findings derived from urban metrics have revealed spatial patterns of built-up areas, explaining the urban morphology of area. The LEI results have described spatial expansion approaches of built-up area. The rate and intensity of urbanization in Asir during different time periods are found by calculating different indices such as Urban Expansion rate (UER) and Urban Growth Coefficient (UGC) and Urban Expansion Intensity Index (UEII). The results of calculated indices are given in Table 4.

The urban indices show that Asir has recorded the highest rate of urban expansion during 2000-2018 (6.06\%) in comparison to $1990-2000(5.42 \%)$. The urban growth coefficients $(>1)$ during both the time-periods indicate sprawling phenomenon. Time-period 2000-2018 has experience higher sprawling phenomenon (13.30) as compared to 1990-2000 (2.68). Also, time-period 20002018 has witnessed higher intensity of urbanization (1.21) than 1990-2000 when intensity of urbanization was much lower i.e., 0.21 . This demonstrates that urban areas have grown at a very greater extent between 2000 and 2018. As per the categorization of UEI, i.e., “ $<0.28$ (very slow urban expansion), 0.28-0.59 (slow expansion), 0.15-1.05 (medium expansion), 1.05-1.92 (high expansion) and $>1.92$ (very high expansion)" [56], 1990-2000 has witnessed very slow urbanization speed (0.21) whereas 2000-2018 has witnessed high urbanization speed.
The findings derived from urban indices are in agreement with that of derived from spatial metrics and LEI. These findings affirm the prevalence of urban sprawl and relatively rapid and intensive urbanization phenomenon is observed during 2000-2018

Urban growth, industrial advancement and agricultural traditions have brought about serious land cover changes, with large impacts on both the country's ecological components and biodiversity. Since $70 \%$ of the Saudi Arabian biome is desert, the natural vegetation is being altered by the extreme climate variation in this environment, including a scarcity of precipitation and high evaporation due to extreme heat during the day which is further enhanced due to increasing LULC change due to anthropogenic activity and is impacting the region more than natural factors. Due to its favourable climate the Asir region in Saudi Arabia has seen highest urban sprawl and expansion intensity during last two decades. The expanding economic activity and increasing population during the last two decades has offered opportunity for investment in booming sector of real estate thereby a massive increase in urban infrastructure. The Saudi Arabia Govt. offered interest free loan to certain lower income group people which also added to already increasing urbanization in the region. To provide basic essential needs and infrastructure to the increasing population several essential services such as hospitals, roads, schools, mosques etc were also built. Thus, with an urban growth rate of $6 \%$ in last two decades in the region needs a sustainable approach for management of growing cities. The Asir also comprise of major share of agricultural land. Over time, each of the form of expansion infill, outlying and edge expansion has grown in size, suggesting the increased compactness in the central part of the city and rapid consumption of vacant lots and fallow lands in the peripheral zones. A major change is observed in the natural landscape in the peripheral zone to build new houses and utility services. The urban areas in Asir are found to extend outwards intruding the natural vegetation and exposed rocky terrain. Such modification of the natural landscape may have destroyed the natural drainage network in the region and is evident by frequent flash floods in the downslope areas near the hills and in the city. The encroachment in the agricultural land and disturbance in drainage network would also degrade the soil quality of the region which in turn might also impact the overall agricultural productivity. The LEI maps depict a

Table 4. Calculated values of Urban Expansion rate (UER), (UGC), Urban Expansion Intensity Index (UEII) during different timeperiods.

\begin{tabular}{|c|c|c|c|c|c|c|c|}
\hline Year & Total land area $\left(\mathrm{km}^{2}\right)$ & Total Urban land $\left(\mathrm{km}^{2}\right)$ & Population & Time-period & UER & UGC & UEII \\
\hline 1990 & 2286.59 & 69.43 & 1340168 & $1990-2018$ & 5.42 & 2.68 & 0.21 \\
\hline 2000 & 2286.59 & 117.75 & 1687939 & $2000-2018$ & 6.06 & 13.30 & 1.21 \\
\hline 2018 & 2286.59 & 339.7 & 1927087 & & & \\
\hline
\end{tabular}


higher proportion of urbanization by edge-expansion on the north-eastern side during 2000-2018. The expansion by outlying is observed along the roads, transects, and in proximity to already existing urban areas. The results also reveal that urban expansion by outlying approach is found to be more dominant followed by edge expansion and infill during both time periods i.e., 1990-2000 and 2000-2018. However, urban expansion in 2000-2018 is found significantly higher in comparison to that of 1990-2000. The increase in CA and PLAND indicates and is in concurrence with LULC change indicating the increase in built-up area. Along with CA and PLAND and LPI depicts dominance of builtup class in the region. The aggregation of built-up in the last two decades has taken place in the centre of the city as indicated by LPI values. The ED indicates the increase in the built-up patches at the outskirts in the southern direction dominated with agriculture and northern direction dominated with rocky terrain. In 1990 the built-up patches were contagious whereas with time in recent decades the urban built-up patches got more clumped and clustered however the progression was found to be irregular. An increase in the number of the urban patches and thus edge density is also observed. The metrics reveal some clustering of urban patches as well. To affirm the findings derived from spatial metrics, LEI results reveal that urban expansion by outlying followed by edge expansion is observed during 1990-2000 as well as 2000-2018. 2000-2018 has witnessed comparatively more urban expansion. Urban expansion by infill in 2000-2018 followed by 1990-2000 is also observed. This has resulted into clustering of urban patches in the centre and disaggregation of urban patches at the outskirts of the study area.

\section{Conclusions}

The increasing population poses pressure on natural resources including land. Urban sprawl is identified as one of the biggest threats to sustainable urban development. The present study targets to assess the urban dynamics of Asir region during 1990-2018. The study demonstrates comprehensive understanding of urbanization phenomenon using remote sensing, GIS, spatial metrics and landscape expansion index (LEI). It was found that built-up area has shown an increase of $389.27 \%$ over the span of two decades. The conversion of natural features such as exposed rock, scrubland, bare soil and agricultural land to builtup is found as the main cause of urbanization. Seven spatial metrics were chosen to analyze the urban spatial patterns that revealed increase in the dominance of built-up class during the specified time-period. The findings of spatial metrics, LEI and urban expansion indices are in agreement with each other. Further, with help of urban indices, it was observed that rate and intensity of urbanization and sprawling phenomenon is higher during 2000-2018 in comparison to 1990-2000.
This study shows that identification of spatial patterns over the years is helpful in understanding the evolution of cities spatially. Asir region in Saudi Arabia is dominated by natural vegetation region, which is experiencing urbanization in recent decades, thus this study shall be helpful for the decision-makers and policy makers in formulating future policies in line with local needs and socio-economic and environmental factors.

\section{Acknowledgements}

The authors extend their appreciation to the Deanship of Scientific Research at King Khalid University for funding this work through General Research Project under grant number (R.G.P2 /75/41).

\section{Conflict of Interest}

The authors declare no conflict of interest.

\section{References}

1. ANEES M.M., SAJJAD S., JOSHI P.K. Characterizing urban area dynamics in historic city of Kurukshetra, India, using remote sensing and spatial metric tools. Geocarto International, 34 (14), 1584, 2019

2. RAHMAN A., NETZBAND M. An assessment of urban environmental issues using remote sensing and GIS techniques an integrated approach: A case study: Delhi, India Atiqur. PRIPODE Workshop on Urban Population, Development, and Environment Dynamics in Developing Countries, (June), 1. 2007.

3. MEGAHED Y., CABRAL P., SILVA J., CAETANO M. Land cover mapping analysis and urban growth modelling using remote sensing techniques in greater Cairo regionEgypt. ISPRS International Journal of Geo-Information. 4 (3), 1750, 2015

4. LOSIRI C., NAGAI M., NINSAWAT S., SHRESTHA R.P. Modeling urban expansion in Bangkok Metropolitan region using demographic-economic data through cellular Automata-Markov Chain and Multi-Layer PerceptronMarkov Chain models. Sustainability. 8 (7), 686, 2016.

5. BALHA A., SINGH C.K. Predictive Modeling of a Metropolitan City in India Using a Land Change Modeling Approach. In Geospatial Applications for Natural Resources Management (pp. 73-86). CRC Press 2018.

6. MALLICK J., HANG H.T. Landscape Pattern and Dynamics in a Fast-Growing City, Khamis-Mushyet, Saudi Arabia, Using Geoinformation Technology. In Geospatial Applications for Natural Resources Management; 16, 2018.

7. BALHA A., VISHWAKARMA B.D., PANDEY S., SINGH C.K. Predicting impact of urbanization on water resources in megacity Delhi. Remote Sensing Applications: Society and Environment. 20, 2020a

8. BALHA A., SINGH C.K. Urban Growth and Management in Lucknow City, the Capital of Uttar Pradesh. In Geospatial Applications for Natural Resources Management (pp. 109-122). CRC Press. 2018a

9. ZHENG Y., CAPRA L., WOLFSON O., YANG H. Urban computing: Concepts, methodologies, and applications. 
ACM Trans. Intell. Syst. Technol. 5, 3, Article 38 (September 2014), 55 pages, 2014.

10. SHARMA R., GHOSH A., JOSHI P.K. Spatio-temporal footprints of urbanisation in Surat, the Diamond City of India (1990-2009). Environmental Monitoring and Assessment. 185, 3313, 2013.

11. BHARATH H.A., BHARATH S., SREEKANTHA S., DURGAPPA D.S., RAMACHANDRA T. V. Spatial patterns of urbanization in Mysore: emerging Tier II City in Karnataka. Proceedings of NRSC User Interaction Meet-2012, 16 $6^{\text {th }} \& 17^{\text {th }}$, Hyderabad, 2012.

12. SUDHIRA H.S., RAMACHANDRA T.V. JAGADISH K. S. Urban sprawl: Metrics, dynamics and modelling using GIS. International Journal of Applied Earth Observation and Geoinformation. 5, 29, 2004.

13. BHATTA B. Analysis of urban growth pattern using remote sensing and GIS: A case study of Kolkata, India. International Journal of Remote Sensing. 30 (18), 4733, 2009.

14. HEROLD M., SCEPAN J. CLARKE K. C. The use of remote sensing and landscape metrics to describe structures and changes in urban land uses. Environment and Planning A. 34, 1443, 2002.

15. RAMACHANDRA T.V., BHARATH, AITHAL H., VINAY S., JOSHI N.V., KUMAR U., RAO K.V. Modelling Urban Revolution in Greater Bangalore, India , 30th Annual In-House Symposium on Space Science and Technology, ISRO-IISc Space Technology Cell, Indian Institute of Science, Bangalore, 7-8 November 2013.

16. BHATTA B., SARASWATI S., BANDYOPADHYAY D. Urban sprawl measurement from remote sensing data. Applied Geography. 30, 731, 2010.

17. RAMACHANDRA T., AITHAL B.H. Understanding urban sprawl dynamics of Gulbarga -Tier II city in Karnataka through spatio-temporal data and spatial metrics. International Journal of Geomatics and Geosciences, 3, 373, 2013.

18. MALLICK J., AL-WADI H., RAHMAN A., AHMED M. Landscape dynamic characteristics using satellite data for a mountainous watershed of Abha, Kingdom of Saudi Arabia. Environmental Earth Sciences. 72, 4973, 2014.

19. DENG J.S., WANG K., HONG Y., QI J.G. Spatio-temporal dynamics and evolution of land use change and landscape pattern in response to rapid urbanization. Landscape and Urban Planning. 92, 187, 2009.

20. PHAM H.M., YAMAGUCHI Y. Urban growth and change analysis using remote sensing and spatial metrics from 1975 to 2003 for Hanoi, Vietnam. International Journal of Remote Sensing. 32 (7), 1901, 2011.

21. TRIANTAKONSTANTIS D., STATHAKIS D. Examining urban sprawl in Europe using spatial metrics. Geocarto International. 30 (10), 1092, 2015.

22. VANDERHAEGEN S., CANTERS F. Mapping urban form and function at city block level using spatial metrics. Landscape and Urban Planning. 167, 399, 2017.

23. BALHA A., VISHWAKARMA B.D., PANDEY S., SINGH C.K. Predicting impact of urbanization on water resources in megacity Delhi. Remote Sensing Applications: Society and Environment. 20, 2020a.

24. WU J., JENERETTE G.D., BUYANTUYEV A., REDMAN C.L. Quantifying spatiotemporal patterns of urbanization: The case of the two fastest growing metropolitan regions in the United States. Ecological Complexity. 8, 1-8, 2011.
25. REIS J.P., SILVA E.A., PINHO P. Spatial metrics to study urban patterns in growing and shrinking cities. Urban Geography. 37 (2), 2016.

26. TAUBENBÖCK H., WIESNER M., FELBIER A., MARCONCINI M., ESCH T., DECH S. New dimensions of urban landscapes: The spatio-temporal evolution from a polynuclei area to a mega-region based on remote sensing data. Applied Geography. 47, 137, 2014.

27. KANE K., CONNORS J.P., GALLETTI C.S. Beyond fragmentation at the fringe: A path-dependent, highresolution analysis of urban land cover in Phoenix, Arizona. Applied Geography. 52, 123, 2014.

28. SETO K.C., FRAGKIAS M. Quantifying spatiotemporal patterns of urban land-use change in four cities of China with time series landscape metrics. Landscape Ecology. 20, 871, 2005

29. LI C., LI J., WU J. Quantifying the speed, growth modes, and landscape pattern changes of urbanization: A hierarchical patch dynamics approach. Landscape Ecology. 28, 1875, 2013

30. LAUSCH A., BLASCHKE T., HAASE D., HERZOG F., SYRBE R., TISCHENDORF L., WALZ U. Understanding and quantifying landscape structure - A review on relevant process characteristics, data models and landscape metrics. Ecological Modelling. 295, 31, 2015.

31. JIA Y., TANG L., XU M., YANG X. Landscape pattern indices for evaluating urban spatial morphology - A case study of Chinese cities. Ecological Indicators. 99, 27, 2019.

32. LIU X., LI X., CHEN Y., TAN, Z., LI S., AI B. A new landscape index for quantifying urban expansion using multi-temporal remotely sensed data. Landscape Ecology. 25, 671, 2010

33. SHI Y., SUN X., ZHU X., LI Y., MEI L. Characterizing growth types and analyzing growth density distribution in response to urban growth patterns in peri-urban areas of Lianyungang City. Landscape and Urban Planning. 105 (4), 425, 2012.

34. LIU X., MA L., XIA LI X., AI B., LI S., HE Z. Simulating urban growth by integrating landscape expansion index (LEI) and cellular automata. International Journal of Geographical Information Science. 28 (1), 2014.

35. TIAN L., CHEN J., YU S. X. Coupled dynamics of urban landscape pattern and socioeconomic drivers in Shenzhen, China. Landscape Ecology. 29, 715, 2014.

36. BALHA A., SINGH C.K., PANDEY S. Assessment of urban area dynamics in world's second largest megacity at sub-city (district) level during 1973-2016 along with regional planning. Remote Sensing Applications: Society and Environment. 20, 100383, 2020.

37. HUILEI L., JIAN P., YANXU L., YI'NA H. Urbanization impact on landscape patterns in Beijing City, China: A spatial heterogeneity perspective. Ecological Indicators. 82, 50, 2017.

38. YINGBIN HE Y., CHEN Y., TANG H., YAO Y., YANG P., CHEN Z. Exploring spatial change and gravity center movement for ecosystem services value using a spatially explicit ecosystem services value index and gravity model. Environmental Monitoring and Assessment. 175, 563, 2011.

39. YANG Y., LIU Y., LI Y., DU G. Quantifying spatiotemporal patterns of urban expansion in Beijing during 1985-2013 with rural-urban development transformation. Land use policy 74, 220, 2018.

40. LEIBOVICI D.G., CLARAMUNT C., LE GUYADER D., BROSSET D. Local and global spatio-temporal entropy indices based on distance-ratios and co-occurrences 
distributions. International Journal of Geographical Information Science. 28 (5), 2014.

41. MEDLEY K.E., MCDONNELL M.J., PICKETT S.T.A. Forest-landscape structure along an Urban-to-rural gradient. The Professional Geographer. 47 (2), 159, 1995.

42. LUCK M., WU J. A gradient analysis of urban landscape pattern: A case study from the Phoenix metropolitan region, Arizona, USA. Landscape Ecology. 17, 327, 2002.

43. WARRAG E. I., MALLICK J., SINGH R.K. KHAN R.A. Status of dieback of Juniperus Procera (African pencil cedar) in natural stands and plantation in Alsouda highlands, Saudi Arabia. Applied Ecology and Environmental Research. 17 (2) 2019.

44. ABULFATIH H.A. Wild plants of Abha and its surroundings. Saudia Publishing and Distributing House. $\mathbf{5}, 125, \mathbf{1 9 8 1}$

45. Saudi General Authority for Statistics General Authority for Statistics. www.stats.gov.sa/en

46. BINDAJAM A.A., MALLICK J., ALQADHI S., SINGH C.K., HANG H.T. Impacts of vegetation and topography on land surface temperature variability over the semi-arid mountain cities of Saudi Arabia. Atmosphere. 11 (7), 762, 2020.

47. LIU J., LI H., GU H. A color balancing method for wide range remote sensing imagery based on regionalization. In Proceedings of the International Archives of the Photogrammetry, Remote Sensing and Spatial Information Sciences - ISPRS Archives, XL-7/W4, 103, 2015.

48. STROPPIANA D., BORDOGNA G., CARRARA P., BOSCHETTI M., BOSCHETTI L., BRIVIO P.A. A method for extracting burned areas from Landsat TM/ ETM+ images by soft aggregation of multiple spectral indices and a region growing algorithm. ISPRS Journal of Photogrammetry and Remote Sensing, 69, 88, 2012.
49. JENSEN J.R. Introductory digital image processing: a remote sensing perspective (No. Ed. 4). Prentice-Hall Inc, 2013.

50. KONECNY G. Geoinformation: Remote Sensing, Photogrammetry and Geographic Information Systems, Boca Raton: CRC Press, 416, 2014.

51. TILAHUN A. Accuracy Assessment of Land Use Land Cover Classification using Google Earth. American Journal of Environmental Protection. 4 (4), 193, 2015.

52. CHA S., PARK C. The utilization of Google Earth images as reference data for the multitemporal land cover classification with MODIS data of North Korea. Korean Journal of Remote Sensing, 23 (5), 483, 2007.

53. Forman R.T.T. Land mosaics: the ecology of landscapes and regions. NCASI Tech. Bull. 656, 1999.

54. MCGARIGAL K., MARKS B.J. FRAGSTATS: spatial pattern analysis program for quantifying landscape structure. Gen. Tech. Rep. PNW-GTR-351. Portland, OR: U.S. Department of Agriculture, Forest Service, Pacific Northwest Research Station. 122, 1995.

55. LU S., GUAN X., HE C., ZHANG J. Spatio-temporal patterns and policy implications of urban land expansion in metropolitan areas: A case study of Wuhan urban agglomeration, central china. Sustainability. 6 (8), 4723, 2014.

56. AKUBIA J.E.K., BRUNS A. Unravelling the frontiers of urban growth: Spatio-Temporal dynamics of land-use change and urban expansion in greater Accra metropolitan area, Ghana. Land. 8 (9), 131, 2019.

57. MCGARIGAL K., SA CUSHMAN S.A., ENE E. FRAGSTATS v4: Spatial Pattern Analysis Program for Categorical and Continuous Maps. Computer software program produced by the authors at the University of Massachusetts, Amherst. 2012. Available at the following web site: http://www.umass.edu/landeco/research/ fragstats/fragstats.html 